\section{Russian scientist 'tried to smuggle spy device to China'}

\section{Moscow}

A Russian scientist, Vladimir Shchurov, has been accused of attempting to deliver to China an underwater acoustic device which the security service claims could be used to track Russian submarines.

The accusation was made after Shchurov was detained at customs. Russia's Federal Security Service last week searched the laboratory Shchurov heads at the Pacific Oceanological Institute of the Far Eastern branch of the Russian Academy of Sciences, in Vladivostok. It was the security service's second visit to the institute within three months. The papers of a prominent ecologist there, Vladimir Soyfer, were searched in July (Nature 400, 300; 1999).

Shchurov's alleged action could lead to several years in gaol. But he denies any impropriety, and points with pride to the fact that his acoustic device, constructed 20 years ago and designed as a research tool, is still considered by the security service to be a threat to national security.

"Our acoustics laboratory is the only one in Russia that uses the unique technology developed here. But our scientific work cannot find any potential users in Russia," he says. "The contact with the Chinese has allowed us to prolong the research, to buy equipment, and to hire young and talented scientists. As a result, we have been able to make substantial progress with our research. But now attempts are being made to drive us out of the scientific market."

Shchurov argues that he did not need an export licence for the device because it was only to be taken out of Russia for the time needed to conduct experiments on two Chinese scientific ships in the Yellow Sea in October and November. The Russian Academy of Sciences had given permission for the work, he says.

Three years ago, Viktor Akulinychev, director of the Vladivostok institute, signed a contract with China's Harbin Engineering University in Heilongjiang province for testing the Russian techniques of studying underwater noises. Shchurov points out that no-one, including the security service, objected to the arrangement at the time.

"The use of such devices to investigate underwater noises has long been routine," says Shchurov. "The only difference is that this time we were to use Chinese, rather than Russian, scientific ships. Our own scientific fleet cannot afford even a short expedition.” Carl Levitin

\title{
Four front runners in race to become director of Unesco
}

\section{Sydney}

The race to succeed Federico Mayor as director-general of the United Nations Educational, Scientific and Cultural Organization (Unesco) entered its final phase last week with the closure of nominations. Interviews by the 58 -member executive board begin in Paris on 13 October.

Of the 11 candidates for the six-year appointment, all but one declared their bids several weeks ago. The exception is Daniel Janicot of France, who was nominated by Georgia last week. Janicot, at 51, is the youngest candidate and the only internal one, being an assistant director-general in charge of the directorate (known as Mayor's cabinet).

Two candidates, Koichiro Matsuura of Japan (61) and Ismail Serageldin of Egypt (55) began campaigning early and, having secured a number of national endorsements, are thought likely to poll well. A career diplomat, Matsuura is Japan's ambassador to France and knows Unesco well as chair of its World Heritage Committee.

Serageldin, vice-president of the World Bank, was nominated not by his native country but by Burkina Faso, reflecting his involvement in developing countries. As chairman of the Consultative Group on International Agricultural Research, he spoke at the Unesco/ICSU World Conference on Science in Budapest last June, where Sweden surprised many by declaring its vote for him from the platform.

The Saudi Arabian nominee, Ghazi AlGosaibi (59), is ambassador to the United Kingdom and a former academic. He claims to have up to 26 votes from Arab, African and non-Arab Islamic states.

The Australian candidate, Gareth Evans (55), is a lawyer and former foreign minister. He is close to completing visits to 55 members

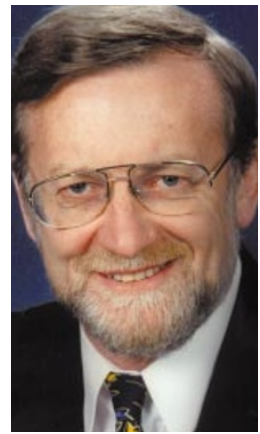

Evans: pledges to cut Unesco bureaucracy. of the executive board and the United States, which he believes can be enticed to rejoin Unesco, and promises to simplify administration and to select and target programmes more rigorously.

The sole female candidate, Rosario Manalo of the Philippines (63), stood unsuccessfully in 1987, when Mayor began his 12 year term. An experienced diplomat and currently secretary general of the Unesco national commission in her country, she will trade on votes from the Asia-Pacific region.

Pal Pataki, Hungary's ambassador to Unesco, and chairman of its executive board, gained exposure to Unesco delegates through his leading role in the World Conference on Science and is the only candidate with strong scientific credentials.

The Sri Lankan, Senake Bandaranayke (61), the Indonesian, Makaminan Makagiansar (70), Lawrence Deighton Carrington of Trinidad and Tobago (58), and Ion Caramitru of Romania (57) are all professors (of archaeology, social sciences, linguistics and drama, respectively). But none is expected to go past the early rounds of voting.

The Matsuura, Serageldin and Evans camps believe their candidates will reach the final rounds. Al-Gosaibi's claims might bring him closest to an early majority. After a maximum of five rounds of voting from 18 to 22 October, one name will emerge for recommendation to 185 member nations invited to the general conference, which concludes on 17 November.

Peter Pockley

\section{Kansas evolution ban under attack}

Washington

Two professional biology organizations have added their voices to criticisms of the decision by the Kansas Board of Education to eliminate the teaching of evolution from the school science curriculum (see Nature 400, 701; 1999).

The board of directors of the American Institute of Biological Sciences has issued a statement describing the decision as "unfortunate", and saying that it "serves only to prevent students from acquiring a comprehensive understanding of modern biology".

A separate statement from the officers and council of the Society for the Study of Evolution describes it as a "retrograde step" to single out certain aspects of science as being unsuitable for the classroom.

"The processes of observation and inference used to support our current understanding of the age of the Universe and of biological evolution are the same as those used in all branches of science," says the statement. "If we abandon the usual procedures of acceptance or rejection of scientific hypotheses in one area of science, then the whole of science is in jeopardy." 